\title{
Networking print cultures: Reclus' Nouvelle Géographie universelle at the Hachette publishing house
}

\begin{abstract}
Historical geographers increasingly address editorial networks as an important element in contextual and situated readings of knowledge production. Recent work has shown that large publishing houses, such as Murray in Britain, Hachette in France and Perthes in Germany, played a primary role in shaping geographical knowledge. This paper's contribution is an analysis of the collaboration between Élisée Reclus (1830-1905) and Hachette over the Nouvelle Géographie universelle (NGU), a classic work in French geography that encompassed nineteen volumes between 1876 and 1894. Drawing upon archival sources, such as the published and unpublished correspondence between Reclus, his collaborators and the publishers, I argue that Reclus' negotiations with this mainstream publishing house were part of a political strategy that was deployed by early anarchist geographers to disseminate their views among broader audiences than just specialist and militant groups. This was a successful bargain for both sides, as there were approximately twenty thousand copies of each volume of the NGU printed. To understand this strategy of public communication and political influence, I examine the international group of anarchist geographers who were involved in Reclus' editorial endeavour within the wider context of Hachette's editorial networks. This involves situating the knowledge they produced in two locations: Paris, where Hachette's headquarters were established, and Clarens, the Swiss village to which Reclus was exiled, and where he worked with collaborators such as Pyotr Kropotkin and Léon Metchnikoff to establish the 'centre of calculation' for his large encyclopaedia.
\end{abstract}

\section{Keywords:}

French Universal Geographies; Publishing industry; Print culture; Anarchist geographies; Mobilities of knowledge

F. Ferretti, "Networking print cultures: Reclus' Nouvelle Géographie universelle at the Hachette publishing house", Journal of Historical Geography, vol. 63, January 2019, https://www.sciencedirect.com/science/article/pii/S0305748817 
Drawing upon recent literature on the geographies of print culture, this paper addresses the relationship between Élisée Reclus (1830-1905) and his primary publisher, Hachette in Paris. Valuable research in historical geography has shown that publishing houses like Murray, in Britain, underpinned ongoing exploration in the British empire and beyond, and played key roles in inspiring travels and in translating 'geographical discoveries' into print. ${ }^{1}$ This work has also demonstrated the importance of publishing processes in building notions of authorial reputation and respectability, and the complexity of the construction of authorship, often involving multiple editorial interventions on the original author's manuscripts. Additionally, recent scholarship considers major publishers in continental Europe, such as Hachette in France and Perthes in Germany, as the first organised agencies for the production of scholarly geography in those countries before the institutionalisation of geography in universities. ${ }^{2}$ The circulation of printed texts is now considered paramount for understanding the construction of geographical knowledge in radically different political and epistemological contexts, from the imperial to the dissident. ${ }^{3}$

This paper extends this literature by analysing the editorial negotiations over the Nouvelle Géographie universelle (New Universal Geography, hereafter NGU), which was published by Hachette from 1876 to 1894 and authored by Reclus, although as I will show the work was a more collective effort. My argument is threefold. First, that the NGU was produced by a collaborative group of scholars which put anarchist politics at its heart. Second, this endeavour was an economic transaction beneficial to both the commercial publishers and the anarchist authors, who consciously established this bargain to disseminate their work to a wide audience. Third, the double localisation of the NGU's editorial offices (in Paris and in Clarens, a Swiss village on Lake Geneva) mattered for both its material shaping and its political signification.

\footnotetext{
${ }^{1}$ I.M. Keighren, C.W.J. Withers and B. Bell, Travels into Print: Exploration, Writing, and Publishing with John Murray, 1773-1859, Chicago, 2015.

${ }^{2}$ F. Ferretti, Les Reclus et la Maison Hachette: la première agence de la géographie française? L'Espace Géographique 3 (2010) 239-252; P. Felsch, Wie August Petermann den Nordpol erfand, München, 2010.

${ }^{3}$ I.M. Keighren, Bringing Geography to Book: Ellen Semple and the Reception of Geographical Knowledge, London, 2010; M. Ogborn, Indian Ink: Script and Print in the Making of the English East India Company, Chicago, 2007; S. Naylor, Historical geography: knowledge, in place and on the move, Progress in Human Geography 29 (2005) 626-634; F. Ferretti, Publishing anarchism: Pyotr Kropotkin and British print cultures, 1876-1917, Journal of Historical Geography 57 (2017) 17-27.
}

F. Ferretti, "Networking print cultures: Reclus' Nouvelle Géographie universelle at the Hachette publishing house", Journal of Historical Geography, vol. 63, January 2019, https://www.sciencedirect.com/science/article/pii/S0305748817 
The paper also addresses and questions two notions that are commonplace in French scholarship: first, the romantic vision of Reclus as a 'heroic geographer' who developed his encyclopaedia in isolation during his Swiss exile. Second, the idea that the NGU underwent a form of 'soft censorship' by its publisher because Hachette did not want a 'combat book' ${ }^{4}$ As an alternative to this I draw upon the concept of the 'bargain', as used by Claudio Minca for analysing the works of Alexander von Humboldt, to highlight the negotiated nature of the production of geographical knowledge intended as a political strategy; one that could be effective even without making its political commitment or affiliation explicit. ${ }^{5}$ This was the case for the 'pure geography' of the eighteenth and nineteenth centuries, and, as I argue below, was also the case for Reclus. ${ }^{6}$

It is impossible to understand the political relevance of the NGU without understanding the spatial and temporal contexts of its production. As such, it is essential to understand the materiality of this editorial endeavour through the analysis of archival sources including the unpublished correspondence between the Hachette editorial office, Reclus and the respective collaborators. This shows that the collaborative group of anarchist geographers who worked to redact the NGU were almost identical to those who participated in the constitution of the first international anarchist organisations in Switzerland in the 1870 s. ${ }^{7}$ Even though the NGU was not specifically labelled as political, Reclus and his anarchist colleagues viewed it as intrinsically useful for their cause due to its effectiveness for public education, its exposition of the federalist manner of deconstructing state territories and its potential for spreading knowledge among different peoples without a pretension to European superiority. ${ }^{8}$

\footnotetext{
${ }^{4}$ R. Lafaille, En lisant Reclus, Annales de Géographie 548 (1989) 447; S. Alavoine-Muller, Élisée Reclus face aux contraintes éditoriales de la maison Hachette, in: I. Lefort and P. Pelletier (Eds), Élisée Reclus et nos Géographies: Textes et Prétextes, Paris, 2013, 145-160. All quotes from texts in French have been translated by the author. Where used, the name Lev Ilič Mečnikov is given in the French spelling - Léon Metchnikoff - that he used to sign his best known works.

${ }^{5}$ C. Minca, Humboldt's compromise, or the forgotten geographies of landscape, Progress in Human Geography 31 (2007) 179-193.

${ }^{6}$ F. Farinelli, Geografia, Torino, 2003.

${ }^{7}$ This parallel between activism and geographical research is now claimed by anarchist geographical scholarship. See S. Springer, The Anarchist Roots of Geography, Minneapolis, 2016.

${ }^{8}$ More detailed information on Reclus' collaborators is given in F. Ferretti, Élisée Reclus: pour une Géographie Nouvelle, Paris, 2014.
}

F. Ferretti, "Networking print cultures: Reclus' Nouvelle Géographie universelle at the Hachette publishing house", Journal of Historical Geography, vol. 63, January 2019, https://www.sciencedirect.com/science/article/pii/S0305748817 
Whilst the 'geographies of the book' are an established area of research in historical geography, recent work by Dean Bond has demonstrated the importance of periodical publication in shaping the production of geographical knowledge from the Enlightenment onwards. ${ }^{9}$ Indeed, it is worth considering the twofold complementarity of book and periodical publication in the Hachette networks and especially in relation to the NGU. First, analysing Reclus' editorial correspondence with Charles Schiffer, I show how the periodical nature of this encyclopaedia was paramount in explaining its shape and size. The NGU was initially printed as a series of weekly issues to be collated into a volume at the end of each year. This implied a strict timing for its editorial working and a situation where its final dimensions remained constantly an open question, allowing the author to renegotiate each year the number of volumes which he needed to finish the work. Therefore, the needs of periodical publishing were an instrument for negotiation in Reclus' hands and meant that the NGU eventually reached nineteen volumes as opposed to the five or six envisaged at the beginning. Second, the constant collaboration among the authors involved in what has been called the 'Hachette geographical agency' allowed exchanges of materials between the editors of books, journals and encyclopaedic works to maximise their dissemination. ${ }^{10}$ This included the publication in book or brochure form of texts formerly published as journal papers or encyclopaedia entries. Therefore, the frontiers between books and periodicals were blurred and complicated, and tracing their connections through the correspondence between authors, editors and publishers can assist in understanding this complexity.

Crucially, I draw from a number of unpublished materials, specifically correspondence between Reclus, his editors and collaborators held at the Institut Français d'Histoire Sociale and the Bibliothèque Nationale de France in Paris, the collection Hachette Livre at the Institut Mémoire de l'Edition Contemporaine in Caen, the Bibliothèque Publique et Universitaire de Neuchâtel (Switzerland) and the State Archive of the Russian Federation in Moscow. This archival base can reveal the relations between the actors involved in the editorial working of the NGU and demonstrates the collective nature of this scholarly endeavour, its contexts and

\footnotetext{
${ }^{9}$ M. Ogborn and C.W.J. Withers (Eds), Geographies of the Book, Farnham, 2010; D. Bond, Plagiarists, enthusiasts and periodical geography: A.F. Büsching and the making of geographical print culture in the German Enlightenment, c.1750-1800, Transactions of the Institute of the British Geographers 42 (2017) 58-71.

${ }^{10}$ Ferretti, Les Reclus et la Maison Hachette.

F. Ferretti, "Networking print cultures: Reclus' Nouvelle Géographie universelle at the Hachette publishing house", Journal of Historical Geography, vol. 63, January 2019, https://www.sciencedirect.com/science/article/pii/S0305748817
} 
its political relevance. In the first section of the paper I set out the initial negotiations between Reclus and Hachette in the aftermath of the 1871 Paris Commune in order to explain the political implications of the bargain established by a radical geographer and a mainstream publisher. Then, I address the work of the NGU editorial office in Paris to show the collaborative nature of the work performed by Hachette's geographical agency. In the third section I analyse the other 'editorial office' in Switzerland to demonstrate the twofold relevance of the NGU's double localisation for its political signification. First, being based in Clarens granted Reclus more independence, as the constraints of distance were used by him to appoint trusted collaborators in Switzerland. Second, this situation provided material and intellectual support for a number of international scholars who collaborated with Reclus and concurrently interacted with the local milieus of the first anarchist organisation in history, the Fédération jurassienne (1871-1880). I conclude by discussing the eventual end of the collaboration between Hachette and these early anarchist geographers.

\section{POST-COMMUNE BARGAINS: NEGOTIATING AN ENCYCLOPAEDIA}

In 1858, Louis Hachette (1800-1864), who was known in France as 'l'Empereur du Livre' due to the increasing power of the publishing house that he had founded in 1826, appointed a young geographer with recent travel experiences in Louisiana, Colombia and the British Isles as a permanent collaborator. ${ }^{11}$ This geographer, Élisée Reclus, was also a political dissident in the Second Empire (1852-1870). However, this did not prevent Hachette from adding him to the team led by Adolphe Joanne (1813-1881), the editor-in-chief of the Guides Joanne series of best-selling travel guides that accompanied 'the spread of railways and railway tourism'. ${ }^{12}$ According to Reclus' biographer, Max Nettlau, Joanne 'occupied a large office that was equipped with all geographical instruments, with 4 or 5 collaborators who travelled when this was necessary for preparing the guides' ${ }^{13}$ In this way, Reclus authored several guides on

\footnotetext{
${ }^{11}$ J.Y. Mollier, Louis Hachette (1800-1864): le Fondateur d'un Empire, Paris, 1999.

${ }^{12}$ D. Nordman, Les Guides-Joanne, ancêtres des Guides Bleues, in: P. Nora (Ed), Les Lieux de Mémoire, Paris, $1997,1037$.

${ }^{13}$ M. Nettlau, Eliseo Reclus: Vida de un Sabio Justo y Rebelde, Volume II, Barcelona, 1930, 158.

F. Ferretti, "Networking print cultures: Reclus' Nouvelle Géographie universelle at the Hachette publishing house", Journal of Historical Geography, vol. 63, January 2019, https://www.sciencedirect.com/science/article/pii/S0305748817
} 
southern France, and, in 1869, a famous introduction for the Dictionnaire géographique de la France that he co-signed with his older brother Élie Reclus (1827-1904). ${ }^{14}$

In the 1860 s, another editorial office for the production of geographical knowledge was established at Hachette's house under the direction of Louis Vivien de Saint-Martin (18021896), one of the most famous geographers at that time. Vivien was appointed to edit the annual series Année géographique and to collect 'all the relevant geographical news of the year' as well as to develop an extensive gazetteer, the Dictionnaire de Géographie moderne, du Moyen Âge et ancienne, which also involved the young Reclus. ${ }^{15}$ Additionally, Hachette launched a monthly journal, Tour du Monde, which was edited by Thomas-Édouard Charton (1807-1890), who was a former Saint-Simonian socialist and an 1848 revolutionary who became acquainted with Reclus and was 'politically very close to him' ${ }^{16}$ Indeed, a letter from the mid 1860s reveals that it was Reclus who appointed Charton as a member of the mutualist movement Crédit au Travail, one of the first crypto-socialist groups that tried to challenge Louis Napoléon's regime. ${ }^{17}$ Geographical editions were also a tool for these politically marginalised scholars to publish and have a voice.

After Louis Hachette's death, his successors and sons-in-law, Louis Breton and Émile Templier, continued the publisher's editorial investment in geography and signed a contract with Reclus for a physical geography of the earth, which would become the first of Reclus' major works, La Terre (1867-1868). In the early years of the Third Republic (1870-1940), Hachette also published work by the first French university geographers, such as Auguste Himly (1823-1906), Auguste Longnon (1844-1911) and Ernest Desjardins (1823-1886), the famous Swiss geographer Arnold Guyot (1807-1884), and, most significantly, the young Paul Vidal de la Blache (1845-1917). In collaboration with Hachette, Vidal de la Blache published his first book, La Vie et les Voyages de Marco Polo (1879), which explicitly aimed to be a

\footnotetext{
${ }^{14}$ Élie and Élisée Reclus, Introduction, in: A.L. Joanne, Dictionnaire Géographique, Administratif, Postal Statistique, Archéologique de la France, Paris, 1869, v-clxxxviii.

${ }^{15}$ Institut Mémoire de l'Edition Contemporaine, Caen (hereafter IMEC), HAC 62.27, Traité récapitulatif; Vivien de Saint-Martin to Hachette, 7 February 1863.

${ }^{16}$ M-L. Aurenche, Édouard Charton et l'Invention du Magasin Pittoresque (1833-1870), Paris, 2002, 392.

${ }^{17}$ Centre d'Accueil et de Recherche des Archives Nationales, Paris (hereafter CARAN), AP 281, Reclus to Charton, n.d.
}

F. Ferretti, "Networking print cultures: Reclus' Nouvelle Géographie universelle at the Hachette publishing house", Journal of Historical Geography, vol. 63, January 2019, https://www.sciencedirect.com/science/article/pii/S0305748817 
geography text for the new republican university system. In 1895, Vidal and Hachette agreed to publish what would become the future classic of the 'French School', Tableau de la Géographie de la France (1903), which was to be 'illustrated with 200 engravings for a volume of approximately 400 pages ... to be printed in 3,000 copies' ${ }^{18}$

The NGU was produced at a time when commercial publishing houses were crucial to the production of works of geography and the relations between geography and the publishing business were increasingly important. As noted above, Hachette was the first systematic producer of geographical knowledge before French universities institutionalised geography. In the first decades of the Third Republic geography was one of the most important emerging scholarly disciplines in France, if not the most important, because of its strategic relevance after the French defeat by Prussia in 1870-1871 - for tackling the so-called défi allemand [German challenge]. This challenge was recognised both at the level of military geography and international scholarly prestige. ${ }^{19}$ Geography also participated in the task of mass schooling which the French state considered vital for consolidating a national identity. Therefore, geography received special protection. Since the 1830s, Hachette had had a de facto monopoly on geographical publications thanks to the orders they received for schoolbooks. This was basically due to the good political relations which its managers established with the successive political regimes of the nineteenth century and beyond in France. ${ }^{20}$ As a result, Hachette took great advantage of the expansion of markets for geographical books in the 1870s and 1880s, and its monopoly started to be challenged only in the 1890s, when other publishers began to work with university geographers. For example, Armand Colin, who published the leading geography journal Annales de Géographie from 1891, and also the famous General Atlas by Vidal de la Blache in 1894. Similarly, in 1899, Georges Masson signed an agreement with the Paris Geographical Society to publish its Bulletin. ${ }^{21}$

\footnotetext{
${ }^{18}$ IMEC, HAC 59.7, Géographie physique de la Terre; HAC 62.8, La vie et les voyages de Marco Polo, 18 January 1879; Tableau Géographique de la France, 18 February 1895.

${ }^{19}$ V. Berdoulay, La Formation de l'Ecole Française de Géographie, Paris, 1981.

${ }^{20}$ J.Y. Mollier, Hachette, le Géant aux Ales Brisées, Paris, 2015.

${ }^{21}$ A. Fierro, Les livres de géographie, in: H.J. Martin and R. Chartier (Eds), Histoire de l'Edition Française, Volume III: le Temps des Editeurs, Paris, 1985, 223.
}

F. Ferretti, "Networking print cultures: Reclus' Nouvelle Géographie universelle at the Hachette publishing house", Journal of Historical Geography, vol. 63, January 2019, https://www.sciencedirect.com/science/article/pii/S0305748817 
The idea that there was a collaborative network of geographers within the Hachette publishing house is fostered by the presence of equipment which aligned it with the contemporary idea of a research laboratory: a Latourian centre of calculation. ${ }^{22}$ First, a geographical library was established in the Hachette building on Boulevard Saint-Germain, 'where all sciences related to geography are represented by approximately 2,000 books and more than 10,000 maps'. In 1880, Élie Reclus was appointed as the director of this library. Another member of the family, their cousin Franz Schrader (1844-1924), constructed a large globe upon which Hachette's geographers compared the results of ongoing explorations and geographical publications. As Schrader remarked in his unpublished recollections, 'A globe at the scale of 1:2,000,000 (therefore, with a circumference of 20 metres) divided into several hundred white sheets, received the summary draft of all new maps in publication ... and facilitated comparative analyses that would have otherwise been very complicated'. ${ }^{23}$ This set of devices was consistent with Latour's definition of a centre of calculation as capable of 'action at a distance' and with Michel Callon's definition of the laboratory as a place for 'the primitive accumulation' of knowledge. ${ }^{24}$ The primary geographical enterprise at Hachette's was Reclus' NGU, which, as will be shown below, established for itself an even more effective centre of calculation to produce geographical knowledge on an unprecedented scale. While the works of Himly, Desjardins, Guyot and Vidal de la Blache had print runs of between a thousand and three thousand copies, there were twenty thousand copies of each volume of Reclus' work, despite its impressive length.

To understand the politics of the NGU project it is first necessary to examine its editorial history, which begins with the Paris Commune (March-May 1871), proclaimed after the insurrection of 18 March 1871. On 4 April, during the first skirmishes between Paris's Garde nationale and Versailles' army, Reclus was taken prisoner and deported to Brest. ${ }^{25}$ The first of those who attempted to defend him were his publishers. Charton, then a member of parliament, acting on behalf of Templier, requested that the government free their prisoner. As a result,

\footnotetext{
22 B. Latour, Science in Action: How to Follow Scientists and Engineers Through Society, Cambridge MA, 1987.

${ }^{23}$ IMEC, HAC 62.27, Achat de la bibliothèque de M. Vivien de Saint-Martin, 27 January 1877; Note sur la préparation et l'exécution de l'Atlas universel Vivien de Saint-Martin et Schrader, 1876-1921.

${ }^{24}$ Latour, Science in Action, 219; M. Callon (Ed), La Science et ses Réseaux, Paris, 1989, 24.

25 G. Dunbar, Élisée Reclus: Historian of Nature, Hamden, 1978.
}

F. Ferretti, "Networking print cultures: Reclus' Nouvelle Géographie universelle at the Hachette publishing house", Journal of Historical Geography, vol. 63, January 2019, https://www.sciencedirect.com/science/article/pii/S0305748817 
Reclus obtained an offer of release from President Adolphe Thiers, with a condition that he would commit 'to remain extraneous to this struggle from now on' ${ }^{26}$ Consistent with his rigid sense of morality, Reclus disdainfully refused this offer, to Charton's disappointment. ${ }^{27}$ Nevertheless, the exchange between Charton and Reclus was not interrupted by the latter's incarceration, and from his prison cell the geographer requested that his friend provide him with 'some little geographical or literary work'. In November 1871, Charton defended Reclus before the war tribunal, which sentenced Reclus to ten years deportation to New Caledonia. ${ }^{28}$ This would have ended all collaboration with Hachette and may have led to the geographer's death. In the following months, Charton visited and assisted Reclus in Versailles prison and wrote to Reclus' mother to request her signature on a petition to Thiers to change the sentence to ten years of exile in a neighbouring country. ${ }^{29}$

This request was successful, and in February of 1872 Reclus joined his brother Élie, who was already a refugee in Switzerland. In Zurich, one of Reclus' first actions was to send a strategic document to Templier: a fourteen page 'Plan for a Descriptive Geography', a provisional title for what would become the NGU. This work was published in weekly parts from 1875, and was collated into volumes each year from 1876. In his 'Plan', Reclus distanced himself from 'most classical work, which viewed true geography as administrative divisions' and paid tribute to his great inspiration, Carl Ritter: 'I would not attempt a work that is similar to Ritter's, addressing every geographical argument in full detail, because I would need a hundred volumes' $\cdot{ }^{30}$ From the beginning, the arguments between Reclus and Templier were more about the work's size and cost - Reclus requested a minimum monthly salary of 600 francs - rather than its potential political impact. A letter from one of Élisée's brothers who worked for Hachette, Onésime Reclus (1837-1916), has been seen by Soizic Alavoine-Muller as 'fundamental' for preventing a 'rupture' between the conservative publisher and the radical geographer. ${ }^{31}$ However, there are no traces of a rupture in the archives, and Onésime's letter

\footnotetext{
26 J. Mistler, La Librairie Hachette de 1826 à nos Jours, Paris, 1964, 243-244; Bibliothèque Nationale de France, Nouvelles Acquisitions Françaises, Paris (hereafter BNF), 22914, 51, Charton to Dumesnil-Reclus, 14 April 1871. ${ }^{27}$ Mistler, La Librairie Hachette, 244.

${ }^{28}$ É. Charton, Correspondance Générale, Paris, 2008, 1596 and 1611.

29 CARAN, AP 281, Reclus to Charton, 27 January 1872; BNF, 22909, 29, Charton to Reclus-Trigant, 24 November 1871.

${ }^{30}$ Institut Français d'Histoire Sociale, Paris (hereafter IFHS), 14 AS 232, Plan de géographie descriptive, 5, 7-8.

${ }^{31}$ Alavoine-Muller, Élisée Reclus.
}

F. Ferretti, "Networking print cultures: Reclus' Nouvelle Géographie universelle at the Hachette publishing house", Journal of Historical Geography, vol. 63, January 2019, https://www.sciencedirect.com/science/article/pii/S0305748817 
merely stated that Templier promised to support Reclus' project before the Hachette council on the condition that 'your geography will not be a religious-politico-socio-militant one ... a combat book' ${ }^{32}$

What is noteworthy is that it is impossible to identify, in Reclus' 'Plan', any intention to write 'a combat book'. As explained above, Reclus had already risked his life by refusing Charton's mediation to free him from prison, and it seems unlikely that he would accept political censorship from Templier. Moreover, the notion of censorship of the NGU was never evoked by Reclus' contemporaries, and Reclus always referred to Templier in a positive light and acknowledged him as a personal friend following his death in $1891 .{ }^{33}$ Indeed, Reclus did not want to publish a politicized book with Hachette because he was fully aware of the workings of the market and had a clear strategy which involved taking advantage of Hachette's centre of calculation to present his geography to a broad public audience. Geography, and 'science' more generally, were deemed progressive by early anarchist geographers even when they were not explicitly labelled as anarchist. ${ }^{34}$ Templier accepted Reclus' 'Plan' unconditionally, including 'the large size you envisage for your work', and offered more money than Reclus requested, which included a supplementary royalty of two centimes for each booklet that was sold. The contract that they signed in July 1872 was substantially based on Reclus' 'Plan'. The contract briefly stated that it was not a 'political' work, but there was no 'censorship' as the sole condition for printing the final work was the author's approval: nobody could manipulate or redact Reclus' text. ${ }^{35}$ This is remarkable when compared with other cases in nineteenth-century geographical publishing, where editorial emendations and manipulations of authors' original manuscripts seemed to be rather the rule than the exception. ${ }^{36}$

The extensive correspondence between Templier and Reclus does not survive in its entirety, but what does is sufficient for charting their negotiations in the years that preceded the publication of the NGU. Reclus was one of the most prolific geographical writers, and in his letters there is a first-hand testimony to his method: 'My manuscript is never finished while I

\footnotetext{
32 IFHS, 14 AS 232, O. Reclus to É. Reclus, 11 April 1872.

${ }^{33}$ P. Reclus, Les frères Élie et Élisée Reclus, Paris, 1964, 89.

${ }^{34}$ Ferretti, Publishing anarchism.

35 IFHS, 14 AS 232, Templier to Reclus, 27 May 1872.

${ }^{36}$ Keighren, Withers and Bell, Travels into Print.
}

F. Ferretti, "Networking print cultures: Reclus' Nouvelle Géographie universelle at the Hachette publishing house", Journal of Historical Geography, vol. 63, January 2019, https://www.sciencedirect.com/science/article/pii/S0305748817 
have it in hand. Normally, I proceed in a linear way, but when I wait for a document, or when I am still unclear on a concept, I shift to another concept leaving lacunas that I will fill later. Sometimes there must be blanks until the last minutes, because numbers and statistics should not get old on the manuscript'. Reclus and Templier engaged in discussions about a 'test chapter' on Switzerland that Reclus sent to define a shared protocol for analysing all regions and countries. After reading this document, Templier argued that the work was scientifically impeccable, but that its tone was too didactic and lacked 'enthusiasm for the great spectacle of nature ... which can give charm, interest and life to a geography book [i.e.] emotions'. According to Templier, a geographer should 'attract, move and be liked, to be read and to instruct' ${ }^{37}$ If the publisher's first concern was the need to sell as many copies as possible, these exhortations did not contradict Reclus' thinking, as is demonstrated in his parallel correspondence with the geographer's other publisher, Hachette's competitor Pierre-Jules Hetzel. ${ }^{38}$ Suggesting that Reclus write 'a literary work, a sort of poem whose hero is the Earth', Templier appeared to be more like Reclus' first reader and supporter than a censor of his political views. ${ }^{39}$

Indeed, the correspondence between 1872 and 1873 shows substantial agreement between the two men, and Templier asked Reclus to stop sending his manuscripts for comment because 'it is unlikely that I have the time to read them before printing', even though this was two years before the first publication. In the following years, the geographer and the publisher also engaged in political discussions about France. Templier disliked Reclus' federalist views, which highlighted regional differences rather than celebrating national unity, but clarified that he did not want to 'counter [Reclus'] geographical ideas'. ${ }^{40}$ Templier was also surprised by Reclus' choice of 'removing Alsace-Lorraine from the volume on France' and including it in the volume on Central Europe, which was almost an outrage to French nationalism after the 1870 defeat by Germany. ${ }^{41}$ In both cases, Reclus' opinion prevailed, and he was free to do as he chose.

\footnotetext{
${ }^{37}$ IFHS, 14 AS 232, Templier to Reclus, 27 May and 31 August 1872.

${ }^{38}$ F. Ferretti, Élisée Reclus, Lettres de Prison et d'Exil, Lardy, 2012.

${ }^{39}$ IFHS, 14 AS 232, Templier to Reclus, 31 August 1872.

${ }^{40}$ IFHS, 14 AS 232, Templier to Reclus; 16 June 1873 and 1 January 1875.

${ }^{41}$ BNF, 22914, 405, Templier to Reclus, 6 January 1876.
}

F. Ferretti, "Networking print cultures: Reclus' Nouvelle Géographie universelle at the Hachette publishing house", Journal of Historical Geography, vol. 63, January 2019, https://www.sciencedirect.com/science/article/pii/S0305748817 
A denial of any political censorship of the NGU was also expressed in 1909 by the geographers Jean Brunhes (1869-1930) and Paul Girardin (1875-1950), who defined it as 'an instrument of propaganda, a tool for [political] conversion'. ${ }^{42}$ Brunhes, a French geographer who worked temporarily in Switzerland, was a supporter and correspondent of Reclus, and was generally considered as an unorthodox author in the French school due to his politics, akin to social Catholicism, while most of the 'Vidalians' rejected explicit social engagement. Indeed, the NGU was not an instrument of explicit propaganda for Reclus, but one which was expected to benefit, if only indirectly, his political cause, as was highlighted by the anarchists who had settled in Switzerland. The Bulletin de la Fédération jurassienne celebrated Reclus' NGU as an expression of 'our feeling of internationality, of cosmopolitanism, which ... is now dominant among the proletariat of the two worlds, fortified by the study of this well-intended geography. [This is] a book of scientific popularization that will make a great contribution to popular education. All workers' societies that have a library should sustain the small sacrifice of spending 50 centimes each week to obtain this work' ${ }^{43}$ Nettlau also viewed the NGU as an intrinsically anarchist book, not because it contained anarchist slogans (it did not) but due to its pluralistic and non-dogmatic approach to problems, the refusal of what would now be called metanarratives. As he put it, 'Only an anarchist could produce such a work in which millions of particularities are presented in a harmonious order, because he possesses the open and flexible mind that is needed to give each problem its own right, without trying to force it into a determined system' ${ }^{4}$

Considering the work's politics is indispensable for understanding Reclus' willingness to establish a bargain with Hachette. In doing so, political value was added to economic advantage. If Reclus' celebrity can partially explain the high sales of the NGU, it was also due to the regular readership provided by the industrial distribution networks that Hachette had organised in France. According to Jean-Yves Mollier, the creation of the Bibliothèque des Chemins de Fer in 1853 underpinned Hachette's overwhelming power in both the printing and distribution of books and journals. Hachette controlled the kiosks established in all French

\footnotetext{
42 J. Brunhes and P. Girardin, Conceptions sociales et vues géographiques: la vie et l'œuvre d'Élisée Reclus, Revue de Fribourg 37 (1905) 286.

43 [J. Guillaume], Variétés, Bulletin de la Fédération Jurassienne, 13 June 1875, 4.

${ }^{44}$ Nettlau, Eliseo Reclus, 30.
}

F. Ferretti, "Networking print cultures: Reclus' Nouvelle Géographie universelle at the Hachette publishing house", Journal of Historical Geography, vol. 63, January 2019, https://www.sciencedirect.com/science/article/pii/S0305748817 
railway stations, more than one hundred in 1890, in addition to between eight and nine thousand bookshops all over France. Hachette's monopoly in book sales in France was also fostered by its dominant position in furnishing the networks of French public libraries and educational institutions, and by an efficient advertising service. ${ }^{45}$ Therefore, Hachette was the first option for any French-speaking author aiming at the widest audience. Reclus was able to reach this audience while retaining control over the content of his work.

Based on the exploration of archival materials including business correspondence, the next two sections of the paper analyse the role played by the two main places where the NGU was produced, Paris and Clarens. They show how the geographical networks of Hachette worked around the editorial offices in Boulevard Saint-Germain, where several of Reclus' relatives, friends and political fellows occupied significant positions, and how the core group of anarchist geographers who redacted the NGU was established around Reclus' house during his exile in Switzerland. An indirect result of there being two places where the NGU's editorial work was carried out is the relative abundance of epistolary sources to reconstruct the material construction of the work. Reclus published weekly issues for almost twenty years through publishers and printers in Paris while he was exiled. Reclus and those working on the NGU were compelled to correspond daily to manage this distant work, although they benefited from an efficient mail system that allowed for the delivery of a letter between Paris and Clarens in twenty-four hours.

\section{THE PARIS EDITORIAL OFFICE}

Scholars of the geography of books have argued that 'the places of production had a significant effect on what "books" themselves actually were', and that the plurality of spaces that characterise the histories of books worked across 'many scales' and connections. ${ }^{46}$ Rediscoveries of the effectiveness of spatial proximity for establishing networks of trust in times of increasing globalization have also inspired commentaries on the ways in which particular places of publication exert an influence in terms of reputation and trust for authors

\footnotetext{
${ }^{45}$ Mollier, Hachette, 2015.

${ }^{46}$ M. Ogborn and C.W.J. Withers, Introduction: book geography, book history, in: Ogborn and Withers (Eds), Geographies of the Book, 8, 19.

F. Ferretti, "Networking print cultures: Reclus' Nouvelle Géographie universelle at the Hachette publishing house", Journal of Historical Geography, vol. 63, January 2019, https://www.sciencedirect.com/science/article/pii/S0305748817
} 
and editors. ${ }^{47}$ In nineteenth-century France, this was the case for Saint-Germain-des-Prés, defined by Mollier as the 'neighbourhood of publishers' in the centre of Paris, where Hachette's headquarters were located. ${ }^{48}$

In Paris, the key actor for the NGU was an obscure Hachette employee, Charles Schiffer, who was appointed by Templier to work with Reclus in February $1875 .{ }^{49}$ To give an idea of Reclus' appreciation of Schiffer's work, the volumes of the NGU all end with a list of acknowledgements, and Schiffer's is the only name that is included in all volumes, with tributes such as saying that 'he devoted himself to being the absent author's substitute' and that he 'invigilated on those thousands of details that are difficult to remember when a work is finished' ${ }^{50}$ However, the physical separation of writer from publisher led to a number of difficulties. For example, Reclus wanted to insert a rich array of thematic maps in his work, but his first efforts to identify trustworthy draftsmen and map-makers in Switzerland were not successful, and the first maps were eventually developed in Paris in the Erhard workshop. Reclus' letters to Schiffer reveal a number of misunderstandings in this process. For instance, he wrote that 'Erhard complains about us and we try our best, but we also have reasons to complain about him'. In his letters to Schiffer, Reclus outlined the essence of his 'mapping philosophy', which was far from pretensions of 'accuracy': 'I definitively prefer the most naïve, the most barbarous map, that has some feeling for nature'. Maps had to be very simple, synthetic and readable: 'No points, no large roads, but very visible traits and only the names of rivers and towns. Erhard knows my wishes, and yet his last maps ... were overloaded with toponyms' ${ }^{51}$ As I explain in the next section, these problems were resolved by the organisation of the Swiss editorial office.

A sample of around a hundred letters that Reclus sent to Schiffer from 1875 to 1904 was deposited at the Neuchâtel Bibliothèque Publique et Universitaire by Schiffer in memory of his

\footnotetext{
${ }^{47}$ B. Heebels, Place-making in publishing: Dutch trade book publishers and the meaning of place in establishing reputation and trust, Geoforum 45 (2013) 248-258.

48 J.Y. Mollier, Édition, Presse et Pouvoir en France au XXe Siècle, Paris, 2008.

${ }^{49}$ BNF, 22914, Templier to Reclus, 27 February 1875.

${ }^{50}$ É. Reclus, $N G U$, Volume II, Paris, 1877, 931 and Volume XVI, Paris, 1892, 817.

${ }^{51}$ Bibliothèque Publique et Universitaire de Neuchâtel (hereafter BPUN), 1990/10, Reclus to Schiffer, 1 August 1875; n.d.; 12 August 1876.
}

F. Ferretti, "Networking print cultures: Reclus' Nouvelle Géographie universelle at the Hachette publishing house", Journal of Historical Geography, vol. 63, January 2019, https://www.sciencedirect.com/science/article/pii/S0305748817 
'collaboration in this work'. Reclus' letters reveal many working details of the NGU, as well as the networked synergies that operated within the Hachette geographical agency. These included mutual proofreading. For instance, Reclus was requested to 'read the proofs of Vivien de Saint-Martin's Dictionary' and, in compensation, he counted on a team of proof-readers in Paris. ${ }^{52}$ Among the most significant letters in the correspondence between Reclus and Schiffer are exchanges in the second half of the 1870s which reveal how dramatic changes were made to the NGU. This involved a substantial increase in the number of pages that were requested by the author.

Initially, it was estimated that the size of the work would be five or six volumes of approximately a thousand pages each which would bring together the weekly issues from the previous twelve months at the end of each year. In 1876 Reclus complained about the limited size of the second volume, and Templier allowed him to produce more volumes than agreed 'if you can limit each of them to 40 or 45 issues' rather than publishing excessively long volumes. ${ }^{53}$ An 1878 exchange between Reclus and Schiffer reveals the author's agency and intentionality in this negotiation. The initial plan included a volume on northern Europe that combined Great Britain, Russia and Scandinavia, which went against Reclus' ideas about the spatial contiguity of the areas being analysed under a common regional definition. In this the anarchist geographer challenged the descriptive tradition of French Universal Geographies inaugurated by Conrad Malte-Brun, in which authors did not worry about combining very distant regions (for example, Russia and Iceland) under the common label of 'Northern Europe'. For Reclus, each volume of the NGU should correspond to a consistent and contiguous geographical region. ${ }^{54}$ It was these considerations which Reclus used to argue for increasing the number of volumes. As he put it, 'We should stop the fourth volume with the chapter on Iceland, otherwise my first chapter on the Boreal Atlantic will not be justified. However, if we do two volumes, it is impossible to put Scandinavia before Britain .... Geographical order would not be followed, and, most importantly, I will lose the order of my ideas. I would be compelled to change front in the middle of the battle .... Please say this to

\footnotetext{
52 BPUN, 1990/10, Folder's Cover, n.d.; Reclus to Schiffer, 29 June 1875.

${ }^{53}$ BNF, 22914, 421, Templier to Reclus, 26 July 1876.

${ }^{54}$ In the case of the 'Europe of North-East', Reclus defined the North Sea as a sort of Mediterranean connecting the British Isles and the Netherlands, E. Reclus, $N G U$, Volume IV, Paris, 1877.
}

F. Ferretti, "Networking print cultures: Reclus' Nouvelle Géographie universelle at the Hachette publishing house", Journal of Historical Geography, vol. 63, January 2019, https://www.sciencedirect.com/science/article/pii/S0305748817 
Templier .... If I can get rid of Scandinavia for this year [and address the British Isles], I will have more freedom, and can write at the British Museum, which has many advantages for the work' ${ }^{55}$ The needs of weekly (that is, periodical) publishing implied that the contents of each volume remained an open and negotiable issue until the end of each year. Crucially, these constraints were transformed by Reclus into opportunities to increase the size of the NGU and to gain resources for research and updating.

Material constraints also explain the reduction in the time between the completion of the NGU text and its printing, which was ultimately reduced to a few weeks. If the first chapters, roughly corresponding to the first volume, were planned and discussed thoroughly from 1872 (the date of the project and contract) to 1875 (the date of publication of the first weekly issues), the journey from pen to page became increasingly quick in subsequent years. Each week a final manuscript was sent from Clarens to Paris, and the corresponding proofs were sent back to the author. When Reclus had sent his corrections back to Paris, Hachette could send the issue to the printer. It is impossible to define exactly how many days passed between writing and printing each time, and this period changed depending on varied contingencies related to Reclus' travels or the availability of sources. However, the dates of his travels and of the publication of the corresponding issues suggest that the timetable was particularly tight. For Reclus' trips to North Africa in the 1880s and in the Americas from 1889 to 1893, his work on these countries was likely to be published while these journeys were still ongoing.

As for the working of the Paris editorial office, Reclus' first 'scientific' collaborator there was also appointed by Templier, with a role akin to a current 'peer-reviewer'. As the publisher wrote to the geographer, 'I know that you are greedier for useful critics than for eu logies. Thus, I think I would match your views if I ask Ernest Desjardins to send you some remarks on your first chapters'. Templier further clarified that Reclus remained 'the only one entitled to decide what to do with Desjardins's remarks' ${ }^{56}$ Desjardins, mentioned earlier, was already acquainted with Reclus. In an 1871 letter, Desjardins told Templier that he had requested the support of Alfred Dumesnil (1821-1894), Reclus' brother-in-law and a very well-positioned literary critic,

\footnotetext{
55 BPUN, 1990/10, Reclus to Schiffer, 28 August 1878.

${ }^{56}$ BNF, 22914, 396, 419-420, Templier to Reclus, 12 June 1875 and 10 July 1876.
}

F. Ferretti, "Networking print cultures: Reclus' Nouvelle Géographie universelle at the Hachette publishing house", Journal of Historical Geography, vol. 63, January 2019, https://www.sciencedirect.com/science/article/pii/S0305748817 
to seek funding for publishing his works. ${ }^{57}$ In his letters to Reclus, Desjardins wrote that he was trying to read the NGU while imagining the possible reactions of generalist readers. ${ }^{58}$ Concurrently, Desjardins was publishing a large work on historical geography for Hachette, Géographie historique et administrative de la Gaule romaine, for which he exchanged sources with Reclus. ${ }^{59}$

However, the most revealing feature of Hachette's geographical agency was the presence of several of Reclus' relatives and friends at the offices in Boulevard Saint-Germain. Thus, Dumesnil collaborated with Hachette in his role as editor of the collected works of the famous poet and left-wing politician Alphonse de Lamartine (1790-1869) ${ }^{60}$ He participated in the production of the NGU as a proof reader, and was a source of important information for the chapter on Normandy. ${ }^{61}$ Onésime Reclus started collaborating with Hachette in the 1860s and joined his brother in the editorial office of the Guides Joanne. He later worked as a sub-editor of Le Tour du Monde in collaboration with Charton, replacing Élisée who was then in prison, but who endorsed the choice of Onésime as his successor. ${ }^{62}$ Templier's letters show that the younger brother was another of the NGU's proof-readers in Paris after the author's 'first correction' ${ }^{63}$

The eldest of Reclus' brothers, Élie, whose work on anarchist anthropology has recently been rediscovered, was appointed as the director of Hachette's research library in 1880 after returning from his post-Commune exile in Switzerland, Great Britain and the United States. ${ }^{64}$ This library, referred to above, comprised the book collection purchased by Hachette from Vivien de Saint-Martin. It became a specialised collection of geographical books and journals for internal use, permitting all Hachette's authors access to basic information for their publications. Working there from 1880 to 1894, Élie Reclus, also a proof-reader and a scientific

\footnotetext{
${ }^{57}$ IMEC, HAC 20.21, Desjardins to Templier, 9 November 1871.

${ }^{58}$ BNF, 22914, 130, Desjardins to Reclus, 27 July 1877.

${ }^{59}$ IMEC, HAC 20.21, Géographie historique et administrative de la Gaule romaine, 22 January 1877.

${ }^{60}$ É. Reclus, Correspondance, Volume II, Paris, 1911, 111.

${ }^{61}$ IFHS, 14 AS 232, Reclus to Dumesnil, 21 October 1876.

62 Mistler, La Librairie Hachette, 261; CARAN, 281 AP, O. Reclus to Charton, 27 July 1870; Charton, Correspondance Générale, 1595.

${ }^{63}$ BNF, 22914, 414, Templier to Reclus, 29 March 1876.

64 Ferretti, Publishing anarchism.
}

F. Ferretti, "Networking print cultures: Reclus' Nouvelle Géographie universelle at the Hachette publishing house", Journal of Historical Geography, vol. 63, January 2019, https://www.sciencedirect.com/science/article/pii/S0305748817 
advisor for the NGU, could publish his own ethnographic works defending indigenous peoples from European prejudices. ${ }^{65}$ According to Schrader, Élie Reclus was a pivotal figure for Hachette's geographical centre of calculation. He was an intrinsic member of the team that conducted a daily survey of all international geographical and travel literature, constantly producing and updating information records on all localities in the world mentioned in these publications. In Schrader's recollections, 'The critical comparison of these records and of the respective sources [constituted the work] through which Hachette's Cartographic Service disseminated this information to the world of geographers' ${ }^{66}$ The ambitions of this team were both editorial and scholarly. While sales were paramount, Hachette's geographers also aimed to create original knowledge to influence international scholarship. This aim could be politically ambivalent: nationalistic for those who wished to respond to the 'German challenge' by fostering the international prestige of French scholarship; internationalist for the anarchist geographers interested in international partnerships to challenge patriotism. A letter from Reclus to Charles Perron on a possible collaboration with German cartographer Albrecht Penck shows his position well: '[Penck] is German, and by our possible alliance we could escape from this dishonourable and awful impasse of "French science and German science". ${ }^{67}$

The last of Reclus' relatives appointed by Hachette was Franz Schrader. Viewed as a great specialist on the Pyrenees, Schrader developed an interest in geography thanks to his cousins and joined Hachette at the request of Élisée and Onésime Reclus. ${ }^{68}$ In the second half of the 1870s, albeit exiled, Élisée Reclus served as a sort of agent for Schrader and recommended him as a possible collaborator for the journal La République française when he arrived in Paris, where 'Hachette and the Alpine Club can guarantee him work for 1,550 francs' ${ }^{69}$ At Hachette, Schrader took over the cartographic office after the retirement of Vivien de Saint-Martin and extensively networked 'to render Hachette a centre of geographical information and original publications' ${ }^{70}$ This included editing Année cartographique and Saint-Martin's Nouveau Dictionnaire de Géographie universelle and, later, the authorship of the Atlas universel de

\footnotetext{
${ }^{65}$ F. Ferretti, The murderous civilisation, cultural geographies 24 (2017) 111-129.

${ }^{66}$ IMEC, HAC 62.27, Note sur la préparation et l'exécution.

${ }^{67}$ É. Reclus, Correspondance, Volume III, Paris, 1925, 100-101.

${ }^{68}$ N. Broc, Franz Schrader, 1844-1924, Geographers Biobibliographical Studies 1 (1977) 97-103.

${ }^{69} \mathrm{BNF}, 22911,243$, letter from Élisée Reclus (no date or addressee).

${ }^{70}$ IMEC, HAC 62.27, Vivien de Saint-Martin to Hachette, 11 June 1880; Mistler, La Librairie Hachette, 267.
}

F. Ferretti, "Networking print cultures: Reclus' Nouvelle Géographie universelle at the Hachette publishing house", Journal of Historical Geography, vol. 63, January 2019, https://www.sciencedirect.com/science/article/pii/S0305748817 
Géographie (known as the Schrader Atlas) as well as many textbooks that sought to establish geography in primary and secondary schools in the Third Republic. ${ }^{71}$

Schrader collaborated with the NGU as a mapmaker, as Reclus stated in his letters to the editors from 1877. In 1881, however, a modernisation of the graphic techniques used allowed Reclus to keep the entire mapmaking process in Switzerland, and enabled Schrader to engage in new work in Paris. Reclus' cousin partially regretted this because, as he wrote, 'I was glad to do something together with you' ${ }^{72}$ In Paris, Schrader was also one of the principal collaborators on another of Hachette's large editorial endeavours, the Dictionnaire de Pédagogie et d'Instruction primaire (1887-1888). This pedagogical dictionary was published under the name of Ferdinand Buisson (1841-1932) and constituted a sort of manifesto for the new pedagogical ideas that were associated with the secular and popular characteristics of the primary school systems that were promoted by the Third Republic. ${ }^{73}$ However, recent studies have shown that the editor was actually James Guillaume (1844-1916), a Swiss anarchist friend of the Recluses and co-founder of the Fédération jurassienne, which also included Reclus and Pyotr Kropotkin. ${ }^{74}$ In 1878, Guillaume left Neuchâtel for Paris, where he edited the dictionary from until 1886, while Buisson was busy with a senior appointment at the Ministry of Education. Guillaume also wrote many of the anonymous entries, which represented, with the articles that were signed by him, more than the half of this monumental work of almost six thousand pages. ${ }^{75}$

Other anarchists, such as the Reclus brothers and Paul Robin, contributed to the Dictionnaire de Pédagogie. ${ }^{76}$ For them, secular education was a crucial battlefield against clerical and conservative tendencies in society, which further explains their willingness to collaborate with progressive liberals like Buisson. French scholars have defined the contribution of geographers

\footnotetext{
${ }^{71}$ I. Lefort, La Lettre et l'Esprit, Paris, 1992.

72 BNF, 22914, 374, Schrader to Reclus, 9 February 1881.

73 P. Dubois, Le Dictionnaire de Pédagogie et d'Instruction Primaire de Ferdinand Buisson: Répertoire Biographique des Auteurs, Paris, 2002, 14.

74 IMEC, HAC 16.3, Guillaume to Breton, 4 November 1910.

75 Dubois, Le Dictionnaire de Pédagogie, 82. This was approximately equivalent to the size of the NGU (more than seventeen thousand pages), given their different formats of pagination.

${ }^{76} \mathrm{~F}$. Ferretti, The spatiality of geography teaching and cultures of alternative education: the 'intuitive geographies' of the anarchist school in Cempuis (1880-1894), cultural geographies 23 (2016) 615-633.
}

F. Ferretti, "Networking print cultures: Reclus' Nouvelle Géographie universelle at the Hachette publishing house", Journal of Historical Geography, vol. 63, January 2019, https://www.sciencedirect.com/science/article/pii/S0305748817 
to the Dictionnaire as 'the Schrader System', to highlight his coordination role. ${ }^{77}$ As JeanPierre Chevalier noticed, this resulted in a strong presence of citations from Reclus, which enhanced his influence among geography teachers. ${ }^{78}$ Guillaume also served as an editor for the second edition of Joanne's Dictionnaire de la France (1905), which included Schrader and all three Recluses who were appointed by Hachette: Élisée, Élie and Onésime. This new dictionary was Guillaume's primary job between 1887 and 1904, and provides an idea of the material extent of the contribution that the Swiss anarchist provided for Hachette's publications. Several of Guillaume's notes also counter the idea of 'censorship' at Hachette's, as the Swiss anarchist wrote to his parents and friends in Switzerland that 'our collective enterprise leaves full freedom and responsibility for their opinions to all contributors', claiming that 'I had complete freedom of expression $\ldots$ and did not have to sacrifice any of my opinions' ${ }^{79}$

This section has shown that the corridors of Hachette's building on Boulevard Saint-Germain were populated by Reclus' friends, relatives and political fellows who could help the anarchist geographer keep an eye on the production of his work from his exile in Switzerland. From the 1860s to the 1910s, Hachette's major geographical and pedagogical endeavours were widely contributed to by anarchists and other political radicals. This demonstrates the breadth of geographers' networked collaborations at Hachette's and provides an understanding of the strategic importance, for political dissidents, of publishing with big houses to obtain material support and a public voice. ${ }^{80}$ It also provides further arguments for the importance of particular places in the formation of knowledge. If the Parisian editorial networks can explain the development of Hachette's geographical agency and the importance for Reclus of establishing a bargain with the most prestigious and prolific French publisher, the geographer's exile in French Switzerland, a region then sheltering all kinds of radical activists and political refugees, fostered Reclus' interest in the political side of this bargain. This involved the establishment in

\footnotetext{
77 J.P. Chevalier, Du Côté de la Géographie Scolaire: Matériaux pour une Epistémologie et une Histoire de l'Enseignement de la Géographie à l'Ecole Primaire en France, Paris, 2003.

78 J.P. Chevalier, Élisée Reclus, la géographie scolaire et le Dictionnaire de Ferdinand Buisson, in: J.P. Bord, R. Cattedra, R. Creagh, J.M. Miossec and G. Roches (Eds), Élisée Reclus-Paul Vidal de la Blache: Le Géographe, la cité et le monde, hier et aujourd'hui, Paris, 2009, 250

${ }^{79}$ Dubois, Le Dictionnaire de Pédagogie, 82 and 12; M. Vuilleumier, James Guillaume, sa vie, son œuvre, in: J. Guillaume, L'Internationale: Documents et Souvenirs, Volume I, Paris, 1909, xix.

${ }^{80}$ Ferretti, Publishing anarchism.
}

F. Ferretti, "Networking print cultures: Reclus' Nouvelle Géographie universelle at the Hachette publishing house", Journal of Historical Geography, vol. 63, January 2019, https://www.sciencedirect.com/science/article/pii/S0305748817 
Clarens of the earliest group of anarchist geographers, who worked together both intellectually and politically.

\section{THE CLARENS EDITORIAL OFFICE}

From 1878 to 1889 , Reclus' house in Clarens was the centre of the Swiss side of the NGU's collective editorial process. A visit of Élie Reclus to Clarens to help his brother was the occasion for an important account of Élisée's style of work. In a private letter to his wife, the elder brother expressed his concerns:

$\mathrm{He}$ is an excessive work-addict, he spares only seconds of his time .... [T] his year he is overloaded, he even agreed to do the second edition of the volume on France .... An entire squad of geographers from Hachette or Petermann could not put together the work he does .... [Léon] Metchnikoff was appointed to teach Geography at Neuchâtel University based on his recommendation, but he will only be there a day per week and will still have time to work on Élisée's notes. ${ }^{81}$

Reclus' almost maniacal encyclopaedism was also witnessed by Kropotkin, who wrote that, for each volume, Élisée 'consulted approximately 1,000 books and articles. A volume or a paper was sometimes consulted only to change an adjective somewhere .... [No] line in the large work was not written by his hand' ${ }^{82}$ Consulting the manuscript of the NGU, which survives at the Neuchâtel library, confirms that it was entirely written by Reclus. However, this does not undermine the importance of the collaborators' work. The order of the lines in the manuscript suggests that the final redaction occurred when the collective work, which Élie Reclus defined as Élisée's paperasses (rough notes), was already in a mature phase.

Given Reclus' celebrity and Hachette's performance in terms of sales and book distribution, the fact that the NGU proved profitable was not surprising. The most original element was what Reclus did with his income from it. The great commercial success of the first published booklets suggested that it would be possible for Reclus to use part of his royalties to pay

${ }^{81}$ IFHS, 14 AS 232, Élie Reclus to N. Reclus-Reclus, 21 August 1883.

82 P. Kropotkin, Élisée Reclus, Les Temps Nouveaux, 15 July 1905, 2.

F. Ferretti, "Networking print cultures: Reclus' Nouvelle Géographie universelle at the Hachette publishing house", Journal of Historical Geography, vol. 63, January 2019, https://www.sciencedirect.com/science/article/pii/S0305748817 
collaborators to alleviate his workload. Templier endorsed this idea, and offered him 300 francs a month on this basis. ${ }^{83}$ While Templier, the prudent businessman, suggested that the geographer should not appoint too many 'mouths to feed', a partial list of the mouths that Reclus effectively fed in Switzerland demonstrates that he had different ideas and favoured mutual aid towards other anarchist exiles or activists who were in difficult personal and professional situations. This was the case with, to mention only the most famous, Kropotkin, Metchnikoff, Gustave Lefrançais, Charles Perron, Michail Dragomanov, Henri Sensine, Luigi Galleani, Nadine Kontchewski (Metchnikoff's stepdaughter) and her husband Leonid Chichko.

Gustave Lefrançais (1826-1901) was a schoolteacher and agitator among the Parisian proletariat, a survivor of the 1848 revolution and the first secretary of the 1871 Paris Commune. After the Bloody Week of May 1871, he fled to Switzerland to escape a death sentence. ${ }^{84}$ There, he was the president of the opening session of the 1872 Saint-Imier Congress, an event that has been canonised as the birth of organised anarchism. Crucially, he served as the editorial secretary of the NGU until 1881, when he could return to France after the amnesty granted to the communards. ${ }^{85}$ Lefrançais was also a collaborator on the anarchist journal Le Travailleur, which was published from 1877 to 1878 and is significant because it was edited concurrently with the NGU and involved the same pool of collaborators and similar themes. Reclus and Perron were included on the editorial board, and Lefrançais, Metchnikoff and Dragomanov were regular collaborators (Kropotkin joined the NGU group a few years later). While working with Reclus at the NGU, Lefrançais publicly discussed the definition of 'anarchy' with him. This prompted Reclus to comment to the other editor of Le Travailleur, Rodolphe Kahn, who was also a French activist refugee in Lausanne, that 'I will respond to Lefrançais, but to respond well [with] three pages will not suffice, nor a full article: I would need an entire book' ${ }^{86}$ The journal was produced in the printing shop of the Russian exiles in Geneva, named Rabotnik (The Worker), and published papers by Metchnikoff on social struggles and mutual aid in Japan, and by Dragomanov on struggles for autonomy in Ukraine, which paralleled several topics that were concurrently addressed in the NGU. Indeed, the political reputation of the

\footnotetext{
${ }^{83}$ BNF, 22914, 394, Templier to Reclus, 20 July 1875.

${ }^{84}$ G. Lefrançais and A. Arnould, Souvenirs de deux Communards Réfugiés à Genève, 1871-1873, Geneva, 1987.

${ }^{85}$ BNF, 16798, Reclus to Pelet, 11 January 1881.

${ }^{86}$ Amsterdam, International Institute of Social History (IISH), Élisée Reclus Papers, Reclus to Kahn [1878].

F. Ferretti, "Networking print cultures: Reclus' Nouvelle Géographie universelle at the Hachette publishing house", Journal of Historical Geography, vol. 63, January 2019, https://www.sciencedirect.com/science/article/pii/S0305748817
} 
NGU team features in a humorous episode recounted by Reclus to one of his fellow anarchist geographers, Attila De Gerando (1847-1897), a French intellectual who was settled in Hungary. Someone had knocked on Reclus' door looking for a job, and, as this person seemed excellent, Reclus was about to appoint him to the NGU when some details made the geographer change his mind and suspect that the man 'was a spy who was sent from Versailles' ${ }^{87}$

Charles Perron (1837-1909) was the author of most of the 6,813 thematic maps that accompanied the text of the NGU. A former internationalist activist and Mikhail Bakunin's closest collaborator in Geneva, he was appointed in 1876 based on a contractual clause that Reclus had requested from Templier in 1872, stating that Reclus had right to extra salary when producing 'by [him]self maps or diagrams that are ready for engraving' ${ }^{88}$ At a time when French scholars had started to include maps, drawings, diagrams and, later, photographs in geography books, Reclus was increasingly interested in the strategic value of such images for maintaining control of his work. ${ }^{89}$ As recent studies have demonstrated, Reclus was fully aware of the ideological nature of maps, a rather common notion today, but one which was not straightforward at that time. ${ }^{90}$ Therefore, it mattered who drew the maps for the NGU.

Again, material and political influences intersected because Perron's availability resolved the problems Reclus faced having his maps produced by Erhard in Paris. With Perron, he could count on a trusted scholar and political adherent to do an important a part of the work under his direct control in Switzerland. Early correspondence between Reclus and Templier shows that it was initially difficult to find a map-maker at a reasonable price in Switzerland. ${ }^{91}$ In 1876 , Perron's appointment became possible thanks to a technological innovation: the so-called Gillot process (from the name of the inventor, Firmin Gillot). This technique produced small maps in black and white that could be sent to Paris for printing, which skipped the intermediate step of engraving. According to Perron, Reclus had been unhappy with using engraving,

\footnotetext{
${ }^{87}$ IFHS, 14 AS 232, Reclus to De Gerando, 25 June 1877.

88 IFHS, 14 AS 232, Reclus to Templier, 31 May 1872.

89 D. Mendibil, Dispositif, format, posture : une méthode d'analyse de l'iconographie géographique Cybergeo (2008) http://cybergeo.revues.org/16823

${ }^{90}$ F. Ferretti, Pioneers in the history of cartography: the Geneva map collection of Élisée Reclus and Charles Perron, Journal of Historical Geography 43 (2014) 85-95.

${ }^{91}$ IFHS, 14 AS 232, Templier to Reclus, 14 September 1874.
}

F. Ferretti, "Networking print cultures: Reclus' Nouvelle Géographie universelle at the Hachette publishing house", Journal of Historical Geography, vol. 63, January 2019, https://www.sciencedirect.com/science/article/pii/S0305748817 
'because it was performed too mechanically, and in Paris, which was too far to receive his direct advice and highlight certain details based on his wishes' ${ }^{92}$ In 1877 , Reclus wrote to Schiffer that he wanted to create 'all maps with the Gillot process from now on'.93

However, the three most important contributors to the NGU were Dragomanov, Kropotkin and Metchnikoff, all of whom were exiled to Switzerland as opponents of the Russian regime. Their contributions included the volumes that were dedicated to their respective specialities: the fifth on 'European' Russia (Dragomanov), the sixth on Russian Asia and Siberia (Kropotkin) and the seventh on East Asia (Metchnikoff). Though the contributions of these scholars were far from being limited to these parts of Reclus' work, their contemporaries emphasised the importance of their participation. This perception was also indirectly confirmed in a letter that Reclus sent to the Russian colonel Venjukoff - a far cry from anarchist politics - who had also provided the French geographer with information on the Russian empire. Venjukoff had mistakenly identified Dragomanov, Kropotkin and Metchnikoff, rather than Reclus, as the first authors of, respectively, the fifth, sixth and seventh volumes of the NGU. Reclus replied correcting this mistake and adding, ironically, 'For sure, [Dragomanov, Kropotkin and Metchnikoff] helped me very importantly ... but you also contributed. I would not have neglected to mention your name in the acknowledgement sections, but I feared that Colonel Venjukoff would have been uncomfortable among the exiles and banished people' ${ }^{94}$

Mikhail Petrovič Dragomanov (1841-1895) was one of the most famous representatives of the large colony of Slavic refugees in Geneva. Though acknowledged today as a 'Founding Father' of the Ukrainian nation, in his Swiss period (1876-1889) he sided with the Internationalists and expressed federalist views that were akin to those of Pierre-Joseph Proudhon. ${ }^{95}$ Dragomanov strongly distinguished himself from the Russian revolutionaries for their lack of attention to the autonomist struggles of Ukrainians, Poles, Finns and the other nationalities in the Russian empire. ${ }^{96} \mathrm{He}$ was a collaborator on Le Travailleur, where he wrote to counter the

\footnotetext{
92 Brunhes and Girardin, Conceptions sociales et vues géographiques, 361-362.

${ }^{93}$ BPUN, 1990/10, Reclus to Schiffer, 19 April 1877.

${ }^{94}$ Nettlau, Eliseo Reclus, 79.

95 See http://www.dragomanov.info/index.html; M. Dragomanov, A Symposium and Selected Writings, New York, 1952, 73.

${ }^{96}$ M. Dragomanov, Le Tyrannicide en Russie et l'Euvre de l'Europe Occidentale, Geneva, 1881, 3.
}

F. Ferretti, "Networking print cultures: Reclus' Nouvelle Géographie universelle at the Hachette publishing house", Journal of Historical Geography, vol. 63, January 2019, https://www.sciencedirect.com/science/article/pii/S0305748817 
Enlightenment stereotypes of Western freedom and 'Oriental despotism' by focusing on the radical national and social struggles that persisted in the Russian empire. ${ }^{97}$ Here, he expressed his idea of the balance between internationalism and cultural specificities: 'Our cosmopolitanism will not target the destruction of nationalities, which would simply mean the submission of conquered nationalities by the conquering ones and the constitution of privileged social classes. Our cosmopolitanism springs from the revolt of the popular classes, which will include all different nationalities ... within an international free and egalitarian federation that is based on individual autonomy and the federation of free Communes'. ${ }^{98}$

The misunderstanding that viewed Dragomanov as the author of the fifth volume of the NGU, rather than a significant contributor to it, persisted into the twentieth century. ${ }^{99}$ However, this mistake does support the general perception of the importance of his contribution to Reclus' geography, which was acknowledged by the French geographer who wrote that 'Dragomanov ... did not spare any hard work in research and correspondence to suggest the best sources and to correct any mistakes in my work. Rereading the chapters on Russia, I recognise his hand on almost every page'. ${ }^{100}$ Dragomanov's collaboration was also a political choice on Reclus' part. According to Nettlau, involving him 'was the best guarantee for keeping centralist Russian tendencies far from the NGU'. ${ }^{101}$

The association between Reclus and Pyotr Aleksejevič Kropotkin (1842-1921) has been examined elsewhere. ${ }^{102}$ However, it is important to mention Kropotkin's experience of the effects of being part of this group in Switzerland as expressed through his recollections: 'Contact with educated men of similar ways of thinking is what we anarchist writers, scattered by proscription all over the world, miss, perhaps, more than anything else. At Clarens, I had that contact with Élisée Reclus and Lefrançais ... and although I worked for geography, I was

\footnotetext{
${ }^{97}$ L. Wolff, Inventing Eastern Europe: The Map of Civilization in the Mind of the Enlightenment, Stanford, 1994, 165.

${ }^{98}$ M. Dragomanov, Les paysans Russo-ukrainiens sous les libéraux Hongrois, Le Travailleur 1 (1877) 14.

99 Dragomanov, A Symposium and Selected Writings, 137.

100 É. Reclus, $N G U$, Volume V, Paris, 1880, 919.

101 Nettlau, Eliseo Reclus, 79.

102 F. Ferretti, The correspondence between Élisée Reclus and Pëtr Kropotkin as a source for the history of geography, Journal of Historical Geography 37 (2011) 216-222.
}

F. Ferretti, "Networking print cultures: Reclus' Nouvelle Géographie universelle at the Hachette publishing house", Journal of Historical Geography, vol. 63, January 2019, https://www.sciencedirect.com/science/article/pii/S0305748817 
able to concurrently produce even more anarchist propaganda than usual'. ${ }^{103}$ This means that, for Kropotkin, the NGU served as a multiplier of its individual actors' energies, fostering at the same time the scholarly and activist sides of their collaborations, which they saw as complementary rather than competing.

Less well known in Anglophone scholarship is Léon Metchnikoff (1838-1888), who was another Russian exile whose biography, which was sketched by Reclus in 1889, could inspire an adventure novel. ${ }^{104}$ Metchnikoff was both a geographer and a transnational militant. A deserter from a Russian scientific expedition in the Middle East following a duel, he wandered the eastern Mediterranean from 1859 and joined Garibaldi's 'Expedition of the Thousand' in southern Italy in 1860. Seriously wounded at the battle of Volturno, the Russian activist settled in Florence, where, in 1863, he sheltered Bakunin after his escape from Siberia. Italian police sources are rich with anecdotes about their activities, revolutionary and otherwise: 'On Friday night, a small meeting occurred in the house of the well-known Russian Mikhail Bakunin, to discuss the next European war .... At 11 pm, they walked in the street with [Mazzinian leader] Giuseppe Dolfi enjoying the cool weather, and finished the night at the wine-shop of the wellknown Solai, nicknamed Barrel' ${ }^{105}$ In 1865, Metchnikoff moved to Geneva and became acquainted with the Reclus brothers. After a sojourn in Japan from 1873 to 1876, which has been considered crucial for bridging Eastern and Western ideas on revolution, he returned to Switzerland, where his papers for Le Travailleur addressed social reform in Japan and challenged Eurocentric prejudices on what he deemed 'a refined civilisation that has penetrated all social classes'. ${ }^{106}$

Reclus constantly helped Metchnikoff to find supplementary publishing work at Hachette's and offered an inspired eulogy of his linguistic skills to Paul Pelet, another Hachette scholar involved in the NGU editing process:

\footnotetext{
${ }^{103}$ P. Kropotkin, Memoirs of a Revolutionist, Volume II, London, 1899, 234-235.

104 É. Reclus, Préface, in: L. Metchnikoff, La Civilisation et les Grands Fleuves Historiques, Paris, 1889.

105 Archivio di Stato di Firenze, Prefettura del Dipartimento Fiorentino (Archivio Segreto 1857-1864), 23, 7 March 1864.

${ }^{106}$ S. Konishi, Anarchist Modernity: Cooperatism and Japanese-Russian Intellectual Relations in Modern Japan, Cambridge, 2013; L. Metchnikoff, Les paysans au Japon, Le Travailleur 4 (1877) 14.
}

F. Ferretti, "Networking print cultures: Reclus' Nouvelle Géographie universelle at the Hachette publishing house", Journal of Historical Geography, vol. 63, January 2019, https://www.sciencedirect.com/science/article/pii/S0305748817 
He is one of the 100 Russians who speak better Russian, one of the 1,000 Italians who speak better Italian, one of the 2,000 Frenchmen who speak better French. Add Spanish, Portuguese, Japanese, some Chinese, Korean, Manchu, Mongolian etc. etc. and very extensive knowledge, and you may admit that this man can be useful. Would it be possible to use him? ${ }^{107}$

In 1882, Reclus tried to support Metchnikoff's proposal to travel to India, Indochina and Indonesia to provide first-hand materials for the eighth NGU volume, but the trip did not occur due to a lack of money. ${ }^{108}$ This would have provided an original case of a European traveller 'writing under instruction', based on a scholars' agreement rather than the priorities of a colonial institution. ${ }^{109}$ Reclus certainly encouraged travels by other unorthodox explorers to ensure that he had first-hand information about non-European peoples and countries from travellers other than military men, missionaries and colonial functionaries. ${ }^{110}$

At that time, and with the NGU already overpopulated with collaborators, Reclus struggled to secure a permanent wage for Metchnikoff. This was only resolved when Templier agreed to allocate the NGU secretary's salary of 300 francs a month to Metchnikoff after Lefrançais left. ${ }^{111}$ Metchnikoff's correspondence, which partially survives in the State Archive of the Russian Federation, shows that he was the primary scientific informer and advisor for Reclus from 1881 to 1888, the year of his death. In 1889, his posthumous work, La Civilisation et les grands fleuves historiques, was published by Hachette and was edited by Reclus and Schrader in collaboration with Templier. ${ }^{112}$ After Metchnikoff's death, the secretaries and scientific informants for the NGU were the Lausanne schoolteacher and broad supporter of anarchism, Henri Sensine, Metchnikoff's stepdaughter Nadine Kontchewski and her husband Leonid

\footnotetext{
${ }^{107}$ BNF, NAF, 16798, 7, Reclus to Pelet, 11 January 1881.

108 Gosudarstvennyi Arkhiv Rossiiskoi Federatsii, Fondy P-6753, op. 1 (hereafter GARF, 6753), khr 67, 1, Reclus to Metchnikoff, 19 November 1881.

${ }^{109}$ Keighren, Withers and Bell, Travels into Print, 38.

${ }^{110}$ F. Ferretti, Tropicality, the unruly Atlantic and social utopias: the French explorer Henri Coudreau (18591899), Singapore Journal of Tropical Geography 38 (2017) 332-349.

111 GARF, 6753, khr 67, 2 and 5, Reclus to Metchnikoff, n.d. and 2 March 1886.

112 GARF, 6753, khr 67, 2, Reclus to Metchnikoff, 29 July 1887; khr 38, 36, Schrader to Metchnikoff, March 1888.
}

F. Ferretti, "Networking print cultures: Reclus' Nouvelle Géographie universelle at the Hachette publishing house", Journal of Historical Geography, vol. 63, January 2019, https://www.sciencedirect.com/science/article/pii/S0305748817 
Chichko. ${ }^{113}$ Metchnikoff's family, like that of Reclus, was fully inserted into the Hachette business.

This section has shown that both distance and spatial proximity matter in the production of knowledge. Establishing his editorial office in Clarens, far from Hachette's headquarters, allowed Reclus to appoint a team of trusted fellows and specialised collaborators picked from among the anarchist exiles and activists. In Clarens Reclus could have more independence and exert direct control over almost all phases of the NGU's production, including pagination and illustration. He could also enjoy direct interactions with local milieus of activists and exiles which enhanced the NGU's militant reputation, as well as its cosmopolitanism and global reach.

\section{CONCLUSION}

The final NGU volume was published in 1894. Reclus began new negotiations with Hachette to continue publishing updated editions and supplementary material, but the times were changing. Charton had died in 1890 and Templier in 1891, and the new director, René Desclosières, was less sensitive to geography than his predecessors. A small body of letters between Reclus and Desclosières in Autumn 1894 document their 'divorce'. Again, the terms of the discussion were economic rather than political. The publisher first stopped printing the NGU paperbacks, due to alarming data from 'the last months' sales', which appeared to have dramatically decreased compared with twenty years earlier, although the correspondence does not show clear numbers. Reclus' disappointment was expressed on behalf of the last two survivors of his team of collaborators, who were then threatened with unemployment. They were Kontchewski and Élie Reclus, who had left his post at Hachette to follow his brother to Brussels New University. ${ }^{114}$ While this 'alternative school' was very important for allowing the Reclus brothers to experience university teaching, it did not pay its professors. ${ }^{115}$ Thus, the publishing industry remained their source of sustenance. After reflection, Desclosières sent an offer that resolved many of Reclus' problems: a severance package of ' 10,000 francs per year

\footnotetext{
${ }^{113}$ É. Reclus, $N G U$, Volume XV, Paris, 1890, 701.

${ }^{114}$ IMEC, HAC 59.7, Desclosières to Reclus, 3 October 1894; Reclus to Desclosières, 5 October 1894.

${ }^{115}$ F. Ferretti, Teaching anarchist geographies: Élisée Reclus in Brussels and 'the art of not being governed', Annals of the American Association of Geographers 108 (2018) 162-178.
}

F. Ferretti, "Networking print cultures: Reclus' Nouvelle Géographie universelle at the Hachette publishing house", Journal of Historical Geography, vol. 63, January 2019, https://www.sciencedirect.com/science/article/pii/S0305748817 
for 10 years in monthly transfers of 833.33 francs', which included free access to Hachette's library for the Reclus brothers during their trips to Paris. Reclus agreed to these conditions but his collaboration with Hachette did not end there. ${ }^{116}$

Reclus remained involved in producing shortened versions of his work for the publisher, such as a volume on southern Africa, which he synthetized and updated with Onésime's help in 1901. He was also involved in the negotiations between Hachette and foreign publishers for printing editions of the NGU in other languages. In 1904, Reclus wrote to Schiffer to comment on the project of a Spanish translation by Blasco Ibañez (later published as Novísima Geografía Universal) and asked him to 'address this business as rapidly as possible'. There were also negotiations over the possibility of publishing the last piece of Reclus' trilogy, L'Homme et la Terre, which remained open until 1904, when Reclus sent the first two chapters for Desclosières's consideration. However, he confidentially wrote to Schiffer, with some sarcasm, that he doubted that 'the House could afford to publish my nonsense. They will already find that the first page is scabrous'. 117

With the deaths of Templier and Charton, Reclus had lost his cheerleaders at the head of Maison Hachette, and the new leaders appeared to be less appreciative. In addition, Schrader, who had been the lynchpin in the practical relationship between Reclus and Hachette, was sacked on similar grounds in 1912, and strongly complained about that in a letter to Louis Breton. ${ }^{118}$ Again, the correspondence suggests that the reasons for Reclus' progressive estrangement from Hachette were economic rather than political. From beginning to end, the negotiations between Reclus and Hachette over the NGU must be understood as part of the process of producing geographical knowledge through the marketplace for books rather than any editor's will to exercise political control. This paper has shown that print cultures - in both book and periodical form - and the material conditions for producing knowledge within them are indispensable for understanding scholarly geography, especially before its university institutionalisation, and that analysis of correspondence and archives is a fundamental tool for

\footnotetext{
116 IMEC, HAC 59.7, Desclosières to Reclus, 7 December 1894; Reclus to Desclosières, 10 December 1894. ${ }^{117}$ BPUN, 1991/10, Reclus to Schiffer, n.d.; 27 November and 3 February 1904.

118 G. Auriol, Franz Schrader : itinéraires, in: H. Saule-Sorbé (Ed), Franz Schrader 1844-1924: l'Homme des Paysages Rares, Pau, 1997, 19.

F. Ferretti, "Networking print cultures: Reclus' Nouvelle Géographie universelle at the Hachette publishing house", Journal of Historical Geography, vol. 63, January 2019, https://www.sciencedirect.com/science/article/pii/S0305748817
} 
such an archaeology of knowledge. Overall, the evidence demonstrates that the NGU was produced by a collaborative group of anarchist scholars inserted in the wider editorial networks of Hachette in Paris and in the milieus of radical activists then settled in Switzerland.

Examination of the NGU has also shown how this publishing endeavour worked as a bargain for both publisher and author(s). If publishing needs, rather than political concerns, conditioned the negotiations between Reclus and Hachette, it is possible to conclude that the NGU benefited both sides. For the author(s), it provided a prestigious and profitable public outlet. Moreover, the NGU's profits also allowed for the publication of anarchist newspapers, such as Le Révolté (1879-1885), La Révolte (1887-1894) and Les Temps Nouveaux (1895-1914), which were first published with Reclus' donations. ${ }^{119}$ For the publishers, who were clearly informed by a liberal mentality, the political reputation of Reclus, Kropotkin and others was not a problem when the product was a commercial success.

Finally, this work has confirmed the importance of particular places in the production and publishing of knowledge, highlighting the role played by the double location of the NGU's construction, in Paris and Clarens. Paris allowed the construction and popularisation of a political and scholarly discourse thanks to Hachette's material support for geography: the research library, the networks of scholars collaborating with the publisher, and its powerful system of distribution and sales. Clarens allowed Reclus to have more independence and to build his trusted editorial team working 'at home'. Spatial proximity mattered, as this team became the core group of anarchist geographers who met and collaborated thanks to the favourable material circumstances which the NGU provided. Once in Switzerland, scholars such as Reclus, Lefrançais, Kropotkin, Metchnikoff and Perron contributed, by their reputations and their direct support, to the activities of the Fédération jurassienne. Moreover, their involvement in the NGU fostered the internationalist approach of a work which challenged the Francocentric views which otherwise characterised the French tradition of the Géographies universelles. As a result, this paper confirms the idea that scholars' exile experiences can play creative roles in shaping their ideas and careers. ${ }^{120}$

\footnotetext{
119 Ferretti, Élisée Reclus.

${ }^{120}$ F. Ferretti, Geographies of internationalism: radical development and critical geopolitics from the Northeast of Brazil, Political Geography 63 (2018) 10-19.
}

F. Ferretti, "Networking print cultures: Reclus' Nouvelle Géographie universelle at the Hachette publishing house", Journal of Historical Geography, vol. 63, January 2019, https://www.sciencedirect.com/science/article/pii/S0305748817 


\section{Acknowledgements}

This publication was supported by the UCD OBRSS Scheme (research grant R16208). Special thanks to Alun Jones for his rereading and his suggestions. I started this research on Reclus' archives almost fifteen years ago and it would be impossible to list here all the colleagues and friends whom I should acknowledge for all the advice and support (moral and material) I have received during this time. Yet, I must mention at least Marie-Claire Robic, Jean-Louis Tissier, Jean-Yves Puyo, Philippe Pelletier and Béatrice Collignon. Finally, great thanks to the anonymous readers for the JHG for their useful remarks and suggestions and, as usual, to the editor Miles Ogborn, who once again gave me great help improving my text.

F. Ferretti, "Networking print cultures: Reclus' Nouvelle Géographie universelle at the Hachette publishing house", Journal of Historical Geography, vol. 63, January 2019, https://www.sciencedirect.com/science/article/pii/S0305748817 